\title{
英国住房政策阶段性演进评析：对上海住房发展的启示
}

\section{Research on the Periodical Evolvement of Housing Policy in the UK: The Inspiration to Shanghai Housing Development}

颜莉

Yan $\mathrm{Li}$

\begin{abstract}
摘要：通过对英国住房政策沿革内容与成效的分 析, 提炼这些政策的阶段性特征, 比对上海住房发 展的内容与特点, 对上海住房发展所处阶段做出预 判, 并在住房制度、住房供给体系结构与保障水 平、公共住房补贴模式、社区融合和管理方面提出 政策建议。
\end{abstract}

Abstract: The research extracts the periodical characteristics of housing policy in the UK by analyzing its evolvement and development. Under the comparison study of housing policy in the UK and in Shanghai, the proposals on housing supply system and structure, the subsidy mode, community inclusion and management are put forward.

关键词：住房政策；阶段性演进；上海住房发展 Keywords: Housing Policy; Periodical Evolvement; Shanghai Housing Development

上海房地产科学研究院科研发展基金项目“上海市 共有产权保障房定价问题研究”阶段性研究成果
英国是世界上最早城市化和工业化的国家，也是最早对住房市场进行政 府干预的国家。相对于美国住房政策的高度市场化、香港政府对住房市场的 “积极不干预” 政策以及新加坡的威权政府主导下的住房发展模式, 英国的 住房政策由于历时最长、具有典型性和示范性以及对住房发展公平与效率的 兼顾而成为住房政策研究的必要内容。唐尼森 (Donnison) 指出, 判断住房 政策是否成功的标准, 就是政府在面临危机时是否采取了行之有效的应对策 略 ${ }^{[1]}$ 。英国住房政策在应对住房短缺、提供可支付住房、促进大城市住房与 市政规划相结合等方面成效显著, 其采取的三种公共住房政策模式, 即控租、 直接提供公共住房和需求补贴, 至今仍为各国公共住房政策具体实施过程中 采用的主要方式。经过十几年的住房制度改革, 上海率先实施廉租住房制度, 创新性地推出 “共有产权” 住房, 为面对阶段性居住困难的群体建设公共租 赁住房, 大规模供应以动迁家庭为对象的征收安置房, 构建了具有上海特色 的“四位一体” (1) 住房保障体系。相对于英国, 上海住房发展历史短、经验 少、基础薄弱, 因此, 英国住房政策的阶段性演进研究可以帮助上海在住房 政策制定过程中进行阶段性对比和思考, 并学习英国住房政策的具体做法, 在宏观上对上海住房发展阶段进行预判, 在微观上提出具体的执行方针和操 作方案。

\section{1 文献综述与问题的提出}

对英国住房政策的研究主要有三个主要方面, 一是对英国住房供应体系 的研究，包括住房供应类型 ${ }^{[2]}$ 、住房供应体系与规划政策 ${ }^{[3]}$; 二是关于英国 《城乡规划法》第 106 条款配建模式的政策研究 ${ }^{[4,5]}$; 三是关于英国公共住 房制度的分析与评价 ${ }^{[6,7]}$, 另有一些包括英国住房制度的国际比较 ${ }^{[8,9]}$ 和对公 共住房适足权 ${ }^{[10]}$ 、价值理念 ${ }^{[11,12]}$ 的讨论与研究。

这些研究从住房供应模式、供应类型、住房制度建设方面提出了政策建 议，对上海的住房保障制度政策制定有一定参考价值。但是，尚未有文献对 上海与英国住房发展历史的阶段性对比做出判断, 因此, 提出的政策建议与

作者 : 颜莉, 博士, 上海市房地产科学研究院。ritaken@163.com

(1) 指廉租住房、公租住房、共有产权房和征收安置房四种供应内容一体化的住房供应体系。 
上海住房发展特点的匹配性和同步性值得商榷。国际住房发 展历史表明，住房发展具有阶段性发展的渐进特征，因此对 住房发展历史最悠久的英国进行研究, 并与其进行阶段性对 比, 提出行之有效的政策和策略, 不仅具有应用价值, 还具 有深厚的理论价值。

\section{2 英国住房政策沿革}

\section{1 自由放任,适当引导与管制（19世纪中叶一20世纪初）}

19 世纪中叶, 英国政府在住房问题上采取自由放任 的政策, 市场调控是住房市场上唯一的方式, 没有任何形 式的政府干预。19 世纪中后期，城市化与工业化速度加 剧, 大批人口涌人导致住房质量下降、居住环境恶劣, 住 房短缺严重。英国政府开始出台措施, 引导个人和团体建 造高质量的住宅。1848 年《公共卫生法》以条文的形式, 制定了住房在布局、设计、建造等方面的最低标准，从而 对住房建设者加以管制和约束。1915 年, 政府出台了租金 管制政策，由政府制定最高租金，限制房东任意增加租金 牟取暴利。

\section{2 政府干预加强, 直接参与建房（1919-1945 年）}

一战后, 由于退伍军人复原、人口增长、结婚高潮的 出现和家庭结构的变化以及战时房屋停建等, 英国出现了严 重的住房短缺。对贫民窟的清理导致许多人失去住所, 1929 年的经济危机使得住房短缺雪上加霜。这一阶段的住房政策 突出表现为政府直接建房来解决住房需求。1919 年颁布《住 房与城镇规划法》后, 伦敦市政府开始直接建设公共住房, 并以低廉的价格提供给市民租住。但是建设的规模不大，住 房保障体系处于初步成形阶段。

\section{3 政府发挥主导作用, 建立公共住房制度（1946 年一 1970 年代末 )}

二战后, 政府为化解社会危机, 开始大规模干预住房领 域。针对住房资源匮乏, 加紧修复损毁房屋并大量新建公共 住房；针对资源分配不均，政府全面干预住房分配，控制私 人住房建设和出租, 以低租金公共住房来解决低收人人群乃 至更多人群的住房问题, 并从整体规划视角着重新城镇建设, 在很大程度上缓解了住房匮乏、分配不均以及住房资源空间 非均衡问题。

1945 年工党政府上台后将解决住房问题视为福利国家 建设的主要目标之一, 全面介人住房领域, 实行国家直接供 应的公共住房制度。通过土地配额和建筑许可证政策，限制 私有建筑商的发展, 保证公共住房建设。1951 年保守党上 台后继承了这一制度, 公共住房建设得到较大发展。1946-
1979 年期间, 地方政府建设了约 510 万套住房, 以低廉的 租金向国民出租, 基本解决了英国的住房短缺以及低收人家 庭的住房支付问题。

1960 年代后, 住房政策的中心开始转移, 政府逐渐减 少对住房供应的直接参与, 转为提供住房补贴 ; 民间住房协 会则呈现迅速发展的趋势。1974 年颁布的《住房法》完善 了住房补贴体系：一方面是对住房供应方的补贴, 通过资助 住房协会, 使其逐渐取代政府成为社会公共住房的主要供应 者; 另一方面是对住房需求方的补贴, 通过财政补贴和税率 管制的政策影响人们对住房所有权的选择。到了 1960 年代 后期, 自有住房成为住房所有权形式的主体。

\section{4 政府退出住房供应,推行公房私有化（1979-1997年）}

1979 年撒切尔夫人上台后, 强势推行市场主导的住房 政策, 把住房自有化率作为主要的住房政策目标。其核心理 念是 : 在保障实现 “居者有其屋” 的前提下, 政府鼓励居民 加大自由住房消费的力度, 促进住房私有化, 提高居民自有 住房率。一方面, 政府全面退出住房供应, 大力削减住房领 域的财政开支, 严格限制各级政府修建和供应公共住房; 另 一方面, 通过颁布《购买权法》(1980 年)、《住房与控制权法》 (1984 年) 和《住房法》(1986、1988 年) 等法案, 并以变 租金为购房抵押贷款、折价优惠等政策大力推行公房私有化, 鼓励租房者、私有企业和住房协会购买政府公房, 并推动后 两者在住房领域发挥更大作用。

撒切尔政府的住房改革客观上转移了政府对住房保障 的直接责任, 减轻了政府的财政和行政压力。在市场机制 作用下, 中高收人阶层改善了居住环境, 并通过投资住房 获利, 而这一时期的两轮住房价格高涨, 使得低收入群体 陷人生活困难甚至无处栖身的困境。之前建立的公共住房制 度在这一阶段几近消失, 住房市场两极分化局面加剧了社 会矛盾。

\section{5 国家干预与市场调节相结合 (1997 年至今 )}

从1997 年布莱尔的首个执政期开始重视住房过度市场 化带来的问题, 2003 年工党政府加大了对公共住房政策的 制定和执行力度, 既继承了一部分前任保守党的自由主义政 策, 又加强了国家干预, 重新强调政府在住房市场中的主导 作用。1990 年制定的《城乡规划法》第 106 条款在这一阶 段得到实施, 开发商获得规划许可证的前提是承担规划责任, 其中一项重要内容是配建可支付住房。这一时期, 住房保障 的主要形式是建设 “可支付住房” (affordable housing)。此 类住房价格通常是市场价的 $70 \% \sim 85 \%$, 在一定年限内不得 上市销售, 或者只能向特定人群出售。这一时期比较有影响 
的政策包括 : 2003 年副首相办公室 ${ }^{1}$ 制定的白皮书 《可持续 的社区: 建设未来》, 2005 年制定的住房政策五年战略规划 《可持续的社区 : 所有人的家》, 财政部 2004 年发布的《住 房供应评估: 最终报告》等, 都将可支付住房置于重要地位。 2004 年颁布的《住房法》就如何确保建造足够的低收人群 体负担得起的社会公共住房、创建公平良好的住房市场秩序 做出了详细规定。2006 年, 进一步提出分享式产权购房计划, 帮助公房租户、无房或者居住在临时住所的家庭、首次购房 者和特殊岗位人员购买住房。

2011一-2015 年, 英国开始在一系列住房改革措施上推行 可支付住房计划, 在资金来源方面, 改变原有的中央政府筹 资方式, 由地方政府征税来补贴可支付住房建设和租赁; 可 支付房租可享受最低为市场租金 $80 \%$ 的折扣 ; 该计划目标 是五年内提供 150 万套可支付住房。

\section{3 英国住房政策实施成效与特点}

\section{1 住房总体数量在半个世纪内增加了将近一倍}

在 1951 年, 英国的住房总量是 1376.4 万套, 2011 年 为 2275.4 万套 (表 1$)$, 住房总量增加了将近一倍。二战后 英国家庭不断增加, 产生了巨大的住房需求, 成为住房数量 上升的最直接因素。1980 年实施购买权 (Right to Buy) 政 策之后, 配合低息金融政策, 私有住房数量快速增长。1951 年住房私有化比率仅为 $29.6 \%$, 一半以上 $(51.8 \%)$ 的住房 需求是通过市场化租赁实现的。1981 年, 住房私有化比率

\section{表 1 英国历年各种类型住房的数量和比率 (单位 : 万套)}

\begin{tabular}{c|c|c|c|c|c|c|c|c}
\hline 年份 & $\begin{array}{c}\text { 私有 } \\
\text { 住房 }\end{array}$ & $\begin{array}{c}\text { 私有化 } \\
\text { 住房比例 }\end{array}$ & $\begin{array}{c}\text { 私有 } \\
\text { 出租 }\end{array}$ & $\begin{array}{c}\text { 私有化 } \\
\text { 出租比率 }\end{array}$ & $\begin{array}{c}\text { 住房协 } \\
\text { 会出租 }\end{array}$ & $\begin{array}{c}\text { 地方政 } \\
\text { 府出租 }\end{array}$ & $\begin{array}{c}\text { 公共住 } \\
\text { 尼例 }\end{array}$ & $\begin{array}{c}\text { 总计 } \\
\text { 唇数 }\end{array}$ \\
\hline 1951 & 407.4 & $29.6 \%$ & 713.0 & $51.8 \%$ & - & 258.0 & $18.6 \%$ & 1374.4 \\
\hline 1981 & 693.3 & $42.7 \%$ & 495.2 & $30.5 \%$ & - & 435.2 & $26.8 \%$ & 1623.7 \\
\hline 1991 & 1553.2 & $66.0 \%$ & 217.1 & $9.2 \%$ & 71.1 & 513.6 & $24.8 \%$ & 2355.0 \\
\hline 2003 & 1805.4 & $70.0 \%$ & 261.6 & $10.1 \%$ & 184.6 & 325.8 & $19.8 \%$ & 2577.4 \\
\hline 2004 & 1830.6 & $70.5 \%$ & 266.3 & $10.2 \%$ & 200.1 & 298.3 & $19.2 \%$ & 2595.3 \\
\hline 2008 & 1500.8 & $67.4 \%$ & 329.6 & $14.8 \%$ & 195.2 & 198.4 & $17.7 \%$ & 2223.9 \\
\hline 2010 & 1496.3 & $67.0 \%$ & 358.8 & $16.1 \%$ & 197.2 & 187.2 & $17.2 \%$ & 2233.5 \\
\hline 2011 & 1476.0 & $66.4 \%$ & 370.6 & $16.6 \%$ & 201.8 & 180.2 & $16.7 \%$ & 2238.6 \\
\hline
\end{tabular}

注: 英国产权式保障性住房供给列入私有住房供给部分。

资料来源 : 根据参考文献 [12] 数据整理
上升到 $57.6 \%, 1991$ 年则达到 66\%。目前住房私有化率稳定 在 $65 \%$ 左右。

\section{2 公共住房比例较高是英国住房体系的重要特征}

尽管 1980 年代私有化进程加快, 政府持有和出租的住 房数量在减少, 但是公共住房仍然服务于约 500 万个家庭, 约占全国住房总量的 1/3（表 1), 这还不包括产权性质的公 共住房。

\section{3 多元化的住房供给体系与多种住房产品类型的供给}

英国目前实施的是 “市场十保障”住房体系, 从供给内 容上看, 有商品房和保障房; 从产权性质上看, 有租赁住房 和产权住房。可通过三种方式选择拥有私有产权住房：购买 公房、购买新房和公开市场购房 ${ }^{2}$ 。图 1 对英国保障性住房 供应体系和产品类型进行了说明。

在 2000 年前后, 伦敦住房建设进入低谷（2000 年仅建造 1.5 万套住房)，住房短缺使得房价持续上涨。2004 年伦敦市 政规划中为各个郡都设立了详细的住房建设量的标准, 规划预 计到 2016 年伦敦每年需要各种类型的住房约 3 万套, 其中一 半为保障性住房, 而政府建设的保障性住房将占 $70 \%$ 以上 ${ }^{[13]}$ 。

\section{4 配建下可支付住房建设的成效显著}

目前英国约 90\% 的地方政府实施《城乡规划法》第 106 条款（即 S106）, 旨在通过配建方式使开发商承担保障性住

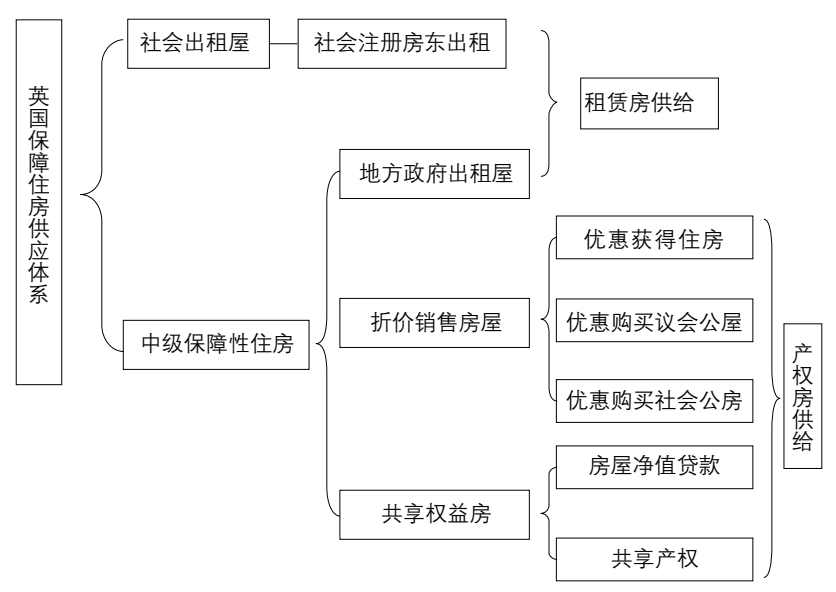

图 1 英国保障住房供应体系

(1) 2006 年更名为社区和地方政府部 (Department for Communities and Local Government)，专门负责英格兰的住房保障政策。

(2) 购买公房：住房协会和地方政府公房的承租人以分享式产权方式购买其承租公房的部分产权, 其余产权由上述机构保留, 购买者付房租。房租 标准是房东所持产权资本价值的 $3 \%$ 。购房者根据自己的经济能力, 分次购买产权, 直至购买全部产权。首次购买时, 购房者必须筹资（可货 款）购买至少 $25 \%$ 的产权。公房出售收入主要用于扩大公房供应，少量被用于与住房有关的其他项目。购买新房：即图 1 中的折价销售房屋， 购房者购买新建住房, 条件与购买公房类似。公开市场购房：针对特定岗位人员、少数公房租户和一些有优先权的首次购房者。购房者和售房 者占有产权的比例是 $75 \%: 25 \%$, 属于产权共享计划。 
房建设的责任，改善低收人家庭的住房条件。1999-2000 年度英格兰可支付住房中有 $1 / 5$ 是通过 S106 协议配建方式 供应的, 到了 2005-2006 年度, 根据 S106, 开发商共提供 23860 套住房, 占可支付住房竣工总量的 55\%。

\section{5 租金控制促进公租房发展}

英国公租房的供给是保障房供给的主体，约占 $20 \%$ 。租 金控制旨在保证公租房租金的可支付性。具体措施有：租 住公租房及其他非市场化房屋居民的房租支出不能超过总 收人的 $25 \%$, 规定租金最高涨幅, 采取一些措施进行控制, 第一种措施是罚款, 比如不符合条件的占用罚款 (Underoccupation Penalty)，即对未按照规定用途使用的公共住房 进行罚款 ; 第二种措施是征税, 比如空置卧室税（Bedroom $\mathrm{Tax})$, 即对公共住房的空置进行征税。

\section{4 英国住房政策阶段性演进分析}

\section{1 住房短缺阶段}

二战后很多欧洲国家都出现了严重的住房短缺, 原因有 两个: 一是战争造成的住宅损毁、住房环境与卫生问题并存; 二是工业化发展带来的进一步城镇化效应, 人口向城市聚集, 大量产业工人迫切需要住房。

针对住房短缺问题, 英国住房政策要点如下 : 第一, 政 府兴建公共住房, 主要是以 “补砖头” 的方式实现住房保障, 公共住房的供给对象主要是低收人人群, 供应方式为租赁; 第二, 通过财政补贴和土地优惠等方式, 鼓励私人开发商建 造市场化住房，并对购房者提供金融支持。

这个阶段的住房政策基本达到了三个目的 : 第一, 解 决低收人人群的住房问题, 尽管各个城市最终的效果不一, 但是最低收人人群的住房保障基本上在这个阶段得以解决; 第二, 对特定人群的住房需求的倾向性政策也起到一定作 用, 特定人群有以下两类, (1) 特定岗位人员、少数公房 租户和一些有优先权的首次购房者，（2）贫民窟里居住多 年需要动迁安置的居民; 第三, 通过住房消费拉动了国家 和地方经济。

这一阶段住房政策产生的问题主要有 : 第一, 政府兴建 公共住房造成财政负担过重，英国政府一度面临人不敷出的 局面; 第二, 公共住房向特定人群倾斜, 分配不公引发社会 争议, 如向公务员倾斜, 造成了一定程度上的不公, 也为一 些人利用这些政策谋取利益制造机会。

但客观而言, 在住房短缺时期, 政府大举兴建公共住房 的政策相比无为而治成效更为显著。鉴于住房介于商品和准 公共产品的特殊性, 无法完全依靠市场实现合理配置, 尤其 在住房短缺时期，政府主导的住房建设和分配可兼顾住房的
效率与公平, 因此在住房发展史上具有重大意义。

\section{2 住房市场供需基本平衡阶段}

政府和开发商共同兴建住房满足住房需求, 在一定时期 之后形成了“保障 +市场” 双轨制的住房供给运行模式。在 此模式下, 政府主要负责公共住房的供给或配建, 或将市场 化住房转化为保障住房用于保证保障性住房的供给, 而市场 化住房需求则通过市场化资源配置的方式解决。

这一阶段, 英国住房政策要点如下。第一, “市场”手 段是住房资源配置的主要方式, 住房私有化是住房政策的导 向性目标。第二, 政府在住房市场上的角色主要有两个, 首 先, 政府仍旧是公共住房的主要供给者, 但不再大举兴建公 共住房, 而是通过配建和转化市场房源去实现 ; 其次, 政府 是住房市场的调控者与监管者, 调控者角色体现在政府对房 地产市场价格的调控, 监管者体现在房地产市场相关法律的 制定与执行。

这个阶段的住房政策基本达到三个目的：第一, 各个 收人阶层按照自己的可支付能力实现住房需求, 形成 “市场 + 保障” 双轨运行模式。第二, 市场化手段配置住房资源成 为住房市场发展的主流。尽管住房政策在这个阶段会在 “市 场” 和 “政府” 两个方向之间摇摆, 但是有两个指标说明了 市场化发展的主流方向, 首先是住房私有化率普遍提高, 撒 切尔时期甚至放弃了公共住房建设, 到 1980 年代, 英国住 房私有化率达到 $60 \%$ 左右, 比第一阶段有大幅度提高; 其 次是商品住房出租比例接近 $20 \%$, 逼近公共出租住房的总和。 第三, 住房私有化率的提高拉动了经济增长, 促进了就业, 提高了城市化率。

这一阶段住房政策产生的问题主要如下: 第一, 住房 过度市场化导致房价䎁升, 撒切尔执政时期经历了两次房 价大涨大跌, 放任房价有悖于政府实现公民住房权的初衷, 但是除了针对房价的调节政策, 英国对过度市场化的后果调 控乏力。第二, 双轨制运行的住房保障体系, 导致夹心层 群体的出现。这些群体产生的原因来自双轨制的内在缺陷: 他们或是在公共住房准人条件上存在差异而无法获得保障, 或是处于保障和市场的夹缝当中无法寻求居住权实现的有 效途径。这一问题夹杂在不同种族、不同收人阶层的混居 政策中, 加大了住房公共政策实施的难度, 也使得英国逐 渐重视混居模式、社区环境及邻里关系, 并在制定政策时 向这些夹心层倾斜。

在住房市场基本平衡的阶段, 住房政策导向在政府和 市场之间摇摆, 总体来看, 市场占据了住房市场资源配置 的主流。然而市场化供应显然无法兼顾效率与公平, 同时 鉴于住房介于商品和准公共产品的特殊性, 其衍生的经济 
功能 (消费、投资) 和社会功能 (社区管理、种族融合) 的重要性逐渐得到显现, 政府职能也逐渐由公共管理转向 公共服务。

\section{3 住房市场发展成熟阶段}

这一阶段, 英国住房发展特点如下。

（1）大部分住房需求通过市场解决, 住房私有化比率高, 英国住房私有化率达到 $60 \%$ 以上。但是大城市的住房私有 化水平较低, 如伦敦的住房私有化率大致为 $30 \%$, 这是因为 城市化率提高到一定水平后, 人口流动性增大、房价偏高, 住房需求从所有权转向使用权。

（2）住房保障手段从实物补贴转向货币补贴。一方面是 从“补砖头” 到 “补人头”。城市化发展使得区域性土地供 给越来越少, 政府主导的公共住房建设不再是住房保障的主 要方式, 对公共住房需求者的货币补贴更有效也更直接。这 方面英国采取的是控租政策, 即规定公租房及其他非市场化 房屋的租金不得超过租户总收人的 $25 \%$, 并规定租金最高涨 幅, 对不符合条件的占用和空置卧室罚款或者征税等。另一 方面是供给补贴向需求补贴的转变。货币补贴直接发放给公 共住房需求者, 而不再给公共住房开发商或者公共住房出租 人提供补贴。

（3）成熟完善的房地产市场机制是市场主导模式顺利运 作的关键。在价格形成机制、供求机制、竞争机制和风险缓 冲机制等方面, 英国都具备成熟完善的法律和制度, 并有相 应的机构监督和实施。

（4）对住房 “软环境” 的重视。相对硬环境建设, 这个 阶段住房政策更注重住房宜居环境的要求, 2005 年提出的 “体面住房” 对住房 “软环境” 提出了八个方面的要求, 对 社区管理、邻里关系和社区人群的就业促进做出了五年规划。 另外, 1990 年提出的第 106 条款不仅对配建进行规定, 也 在一定程度上促进了不同种族、收人阶层的混居, 体现了住 房政策 “包容性” 原则。图 2 是对英国住房政策三个演进阶 段的总结。

\section{5 上海住房发展所处阶段与发展趋势}

\section{1 上海住房发展所处阶段分析}

目前上海住房发展与政策沿革具有以下特点。第一, 虽 然政府主持或者主导的大规模保障性住房建设接近尾声, 仍 有部分公共住房建设在政府主持或者主导下进行; 配建可能 成为下一阶段公共住房建设主要方式。第二, “保障 +市场” 双轨住房供应体系已经形成, 保障房供应品种包括廉租住房、 公共租赁住房、共有产权房和征收安置房, 市场化住房则包 括商品房和二手房; 租售并举是现阶段公共住房政策的主要
供给方式。第三, 住房市场化改革继续深人, 城市经济对房 地产发展仍然存一定程度的依赖，住房政策与产业政策并行。 第四, 政府在住房市场中仍然扮演强势角色, 房价是政府政 策调控的主要内容。

比对前文对英国住房发展各个阶段政策特征的描述，上 海住房市场发展总体处在第二阶段初期。

\section{2 上海住房发展趋势与政策建议 \\ 5.2.1 完善双轨制, 实现公平与效率兼顾}

“双轨制”的住房供应体系运行日渐成熟，但仍旧面临 一些问题：第一，功能处于 “保障” 和 “市场”之间的住 房供应品种如经济适用房、限价商品房等成为很多地方政 府为特定群体 (公务员等) 谋取特殊利益的 “寻租” 工具; 第二, 夹心层群体日益庞大。政策缺乏灵活性、供给机制 缺乏有效过滤, 使得双轨制之间的缝隙日益加大, 管理问 题日益突出。

因此, 建议形成以 “共有产权住房” 为核心的保障性住 房供应机制, 明确政策的保障力度和适用群体。措施上加强 对申请对象的财产审核和收人审核, 对扶持性住房购买者的 准人和退出实行动态管理, 规范其持有住房期间与住房权利 相关的行为。针对 “夹心层” 采用更为灵活的方式, 在设置 新一轮准人标准时, 对收人、面积、户籍等条件进行重新调 整和考虑 ; 针对贷款现金流支付有困难的群体, 除了公积金 外, 可以考虑在商业贷款方面降低首付款或给予一定利息补 贴, 帮助其度过扶持期; 针对购买份额有困难的人群, 建议 实施阶梯式共有产权份额体系。阶梯式产权份额的基本原理 是将政府与购房者的份额比例划分得更贴近购房者的支付能 力, 并对中低收人群体进行再倾斜。

\subsection{2 住房保障内容结构性调整与保障水平的提高}

根据上海市“十二五”住房发展规划, 到“十二五”期 末, 规划实现目标为: 新增供应约 100 万套保障性住房, 其 中廉租住房 7.5 万套, 公共租赁住房 18 万套, 共有产权房 40 万套, 征收安置房 35 万套。从面积上来看, 共有产权房 累计开工达 3000 万 $\mathrm{m}^{2}$, 征收安置房开工建设 3250 万 $\mathrm{m}^{2}$,

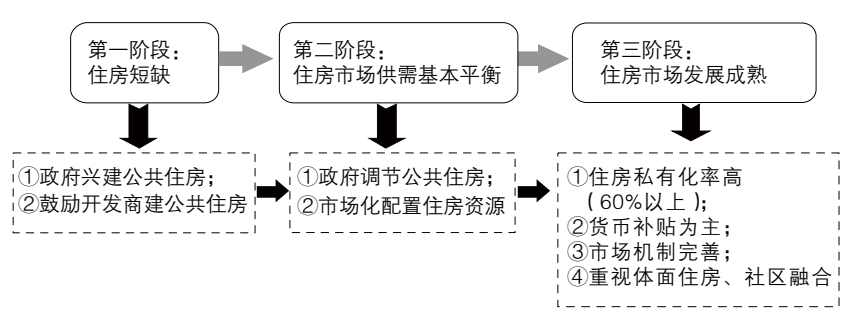

图 2 英国住房政策三阶段演进及特点 
竣工 2960 万 $\mathrm{m}^{2}$, 完成搭桥供应 ${ }^{11} 2985$ 万 $\mathrm{m}^{2[14]}$ 。

从住房保障内容来看, 租赁性住房占比约为 $25 \%$, 产权 房约为 $75 \%$ 。从国际上保障住房的产权性质来看, 产权房比 例偏高, 但是由于上海房价偏高、住房具有财富效应, 目前调 整的必要性不大。产权房中, 共有产权房和征收安置房供给各 约占一半, 因此这两者可以作为今后供给内容结构性调整的重 点。应减少征收安置房的供给量, 原因在于, 第一, 随着越 来越多的征收安置房上市, 其保障性住房的性质将逐渐丧失; 第二, 随着上海城市规划布局战略性调整以及可供住房建设 的土地供给的日渐稀缺, 大规模征收安置房的建设接近尾声。 共有产权房作为下一阶段保障性住房的建设重点, 可以通过 新建和配建双管齐下的方式增加供给, 帮助中低收人阶层实 现“住有所居”, 完成保障性住房向商品化住房的过渡。

住房保障水平是反映住房适度性的主要指标。住房保 障水平由住房保障可供给水平和住房保障需求水平共同决 定。住房保障需求主要受到城市化发展阶段的影响, 呈现倒 “U” 形, 影响因素包括城市化进度、社会阶层和财富分配 情况、住房保障需求的发展趋势等。住房可供给水平则主要 受到 GDP 和财政收人的制约。综合供需情况，每个城市在 住房发展水平的不同阶段都对应着不同的住房保障水平, 即 反映现实供需的住房适度性要求。

如图 3, 目前上海住房保障适度水平处在倒 “ $U$ ” 形曲 线的前端斜率较高点 $\mathrm{A}$ 。从量上看, 供给方面的住房可保障 水平处于持续提升阶段; 需求方面, 人口持续涌人, 住房需 求水平也处于上升期。从质上看, 随着住房保障内容的结构 性调整, 保障性住房品种会在产权形式、补贴模式、优惠方 案上逐步优化, 满足中低收人群体在不同阶段的公共住房需 求。根据现阶段住房需求分类分析, 对公共住房的保障性需 求应继续以租赁政策为主，而扶持性（改善性）消费需求以 产权政策为主, 从保障性需求到改善性需求, 应辅以金融财 税政策的鼓励。2015 年, 上海住房保障供给基本上可以达 到 “十二五” 规划目标所设定的供给量和覆盖面目标, 下一 步政策重点是对保障性住房供给内容结构进行优化, 同时通 过引导住房保障的合理需求, 使可能实现的供给与合理需求 相结合, 逐步提高住房保障水平, 以保证公共住房与经济发 展的同步性与适度性。

\subsection{3 公共住房补贴模式的转变}

在第二阶段, 公共住房补贴模式有两个发展趋势。第一, 补贴方式由 “实物补贴” 向 “货币补贴” 转变。“实物补贴”
适用于住房短缺阶段的住房供给, 在住房供需相对稳定的阶 段, “货币补贴”更符合现实需要, 也具有比较高的效率。 英美两国在货币补贴方面有两种做法均值得效仿, 首先是对 租赁需求实施货币补贴, 发放 “租房券”, 给保障对象更多 的选择权和选择空间, 上海的廉租房和公租房实际上已经部 分地采用了货币方式进行补贴; 其次是对购房需求进行货 币补贴, 补贴方式主要是通过金融支持的方式实现, 比如英 国对购房者的购房需求进行分类，通过 “折价销售产权房” 和 “共享产权房” 两种方式进行产权式公共住房的供给, 对 不同类型的购房者提供不同种类的购房贷款优惠, 帮助其实 现住房私有。第二, 补贴对象从 “供给方” 转向 “需求方”。 与补贴方式向对应, 货币补贴也从对住房开发商的补贴转向 对住房需求者的补贴。英国、美国、香港、日本都采用的是 需求补贴的方式。

因此, 建议在廉租房和公租房 “货币补贴” 的基础上, 向保障住房需求者提供进一步的货币补贴, 租赁式住房需求 提供 “租赁券”, 允许其在商品租赁市场选择适合自己的住 房; 产权式需求则注重金融财税方面的货币补贴, 帮助其拥 有共有产权住房。

\subsection{4 社区融合与管理模式的改变}

不同种族、民族、收人阶层、职业类型的混居和融合, 是英国在第二阶段公共住房政策考虑的重点, 同时社区管理 模式从单一的片区管理转向更具人性化和灵活性的第三方机 构管理。

因此, 政策要点如下 : 第一, 市政规划充分考虑不同收 人阶层的社区的混居, 对中低收人群体的社区硬件建设予以 一定政策倾斜；第二, 对于棚户区或者旧里弄改造过程中迁

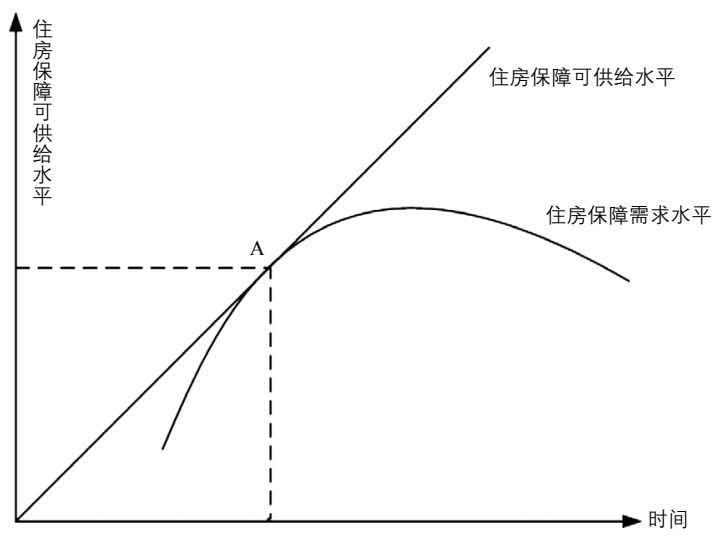

图 3 住房保障水平供求图

(1) 搭桥供应: 主要针对配套商品房, 由政府定向供应给重大工程、重点旧改实施单位, 由动迁单位受理动迁居民购买申请, 并审核报主管部门批 准后，向符合条件的动迁居民开具“配套商品房”供应单，购买人据此与开发商签订（预）销售合同。 
出的人群, 在就业方面予以帮助和指导, 使其尽快融人新的 社区环境和社会生活 ; 第三, “镇管” 模式与 “第三方” 住 房机构管理相结合, 镇管模式只是从行政管理到物业管理的 过渡模式, 在具体社区管理上缺乏灵活性, 可以考虑建立非 营利的第三方住房管理机构, 专司社区融合与发展问题。学 习香港的经验, 这种非营利性机构可以通过参与周边市政规 划, 在商场、停车场设置上向混居社区倾斜, 并将这些商业 设施的盈利转移一部分给非营利性机构。

\section{2 .5 住房公共管理从行政管理向服务社区转变}

第二阶段的住房公共管理除了社区融合和第三方机构 的培育外, 各国 (城市) 的管理方向都发生了转变, 无论 是主张 “市场为主” 的新自由主义还是主张 “政府为主” 的威权主义 (福特主义), 都不约而同地逐步弱化政府行政 管理, 更多地提供社区服务。集中表现在旧房修缮和物业 管理方面。

因此, 政策要点如下。第一, 随着大规模住房建设接近 尾声, 对旧房修缮和改造可能是下一步住房发展的重点。旧 房修缮和改造的技术性指标和规范性文本目前尚在起步阶段, 应抓紧制定。第二, 物业管理方式向多样化转变, 可以考虑 借鉴美国的外包式专业化物业管理模式, 也可以借鉴新加坡 物业管理法制化程度较高的先进经验, 财务核算上还可以借 鉴香港的 “酬金制”, 全面提高物业管理的水平和服务能力。

\section{6 研究展望}

发达国家住房发展与规划过程中有三个方面的考虑 : 第 一, 也是最核心的内容是住房发展的主导力是政府还是市场, 这直接决定了住房供应的内容、公共住房的补贴模式和相关 政策; 第二是住房政策的任务和使命, 在住房发展的不同阶 段, 任务和使命不尽相同, 体现出来的住房发展特点也有所 差异; 第三, 住房环境、社区融合与和谐发展越来越受到各 国 (城市) 的重视, 体现了住房发展 “硬件”与 “软件”结 合与平衡式协调的必要性。

考虑到上海目前住房发展所处的阶段, 住房发展模式、 住房政策和倾向性都必须借鉴先进国家和地区的经验和教 训, 循序渐进、平稳为主。针对上海住房发展过程中的特点 与经验, 下一步相关政策的制定应遵循上述三个方面的考量, 以 “双轨制” 为核心, 继续深化市场在住房资源调节中的作 用, 并将住房环境、社区融合与和谐发展纳人公共住房政策 的主要方面, 走出既符合中国社会主义特色要求, 又具有上 海地方特点的住房发展道路。

注: 文中图片均为作者绘制。

\section{参考文献}

[1] Donnison D V. The Government of Housing[M]. Harmond-sworth: Pengium, 1967: 100.

[2] 刘玉亭, 何深静, 吴缚龙. 英国的住房体系和住房政策 [J]. 城市规划, 2007, 9: 54-63.

[3] 汪军. 英国住房供应体系与规划政策新观察 [J]. 上海城市规划, 2010, 1: 50-54.

[4] Morrison N, Burgess G. Inclusionary Housing Policy in England: The Impact of the Downturn on the Delivery of Affordable Housing through Section 106[J]. Journal of Housing and the Built Environment, 2013, 6: 70-87.

[5] 刘志林, 韩雅飞. 规划政策与可支付住房建设一一来自美国和英国的 经验 [J]. 国际城市规划, 2010, 3: 90-95.

[6] 王兆宇. 英国住房保障政策的历史、体系与借鉴 [J]. 城市发展研究, 2012, 12: 134-139.

[7] 刘朝马.住房保障政策: 英国经验及启示 [J]. 城市问题, 2007, 3: 91-99.

[8] 何静. 国外住房保障制度的评介与启示 [J]. 管理现代化, 2012, 4: 123-125.

[9] 刘波, 赵继敏。世界城市住房保障政策比较研究 [J]. 国际城市规划, 2012, 1: 16-20.

[10] 徐虹.住房保障水平发展趋势分析 [J]. 兰州学刊, 2011, 5: 58-63.

[11] 市婧. 国外住房保障制度主要模式及对我国的启示 [J]. 当代经济管理, 2012, 11: 39-43.

[12] The UK Government. Household Characteristics[EB/OL]. (2012-11-14) [2014-05-07]. https://www.gov.uk/government/collections/householdcharacteristics.

[13] Great London Authority. London Plan March 2015 (Further Alterations to the London Plan)-Ch7 London's Living Places and Spaces[EB/OL]. (201310-14)[2015-06-02]. http://www.london.gov.uk/priorities/planning/londonplan/further-alterations-to-the-london-plan.

[14] 上海市人民政府。上海市国民经济和社会发展第十二个五年规划纲 要 [EB/OL]. (2011-03-02)[2014-05-07]. http://www.shanghai.gov.cn/ shanghai/node2314/node25307/node25455/node25457/u21ai485258.html.

(本文编辑: 张祎娴) 